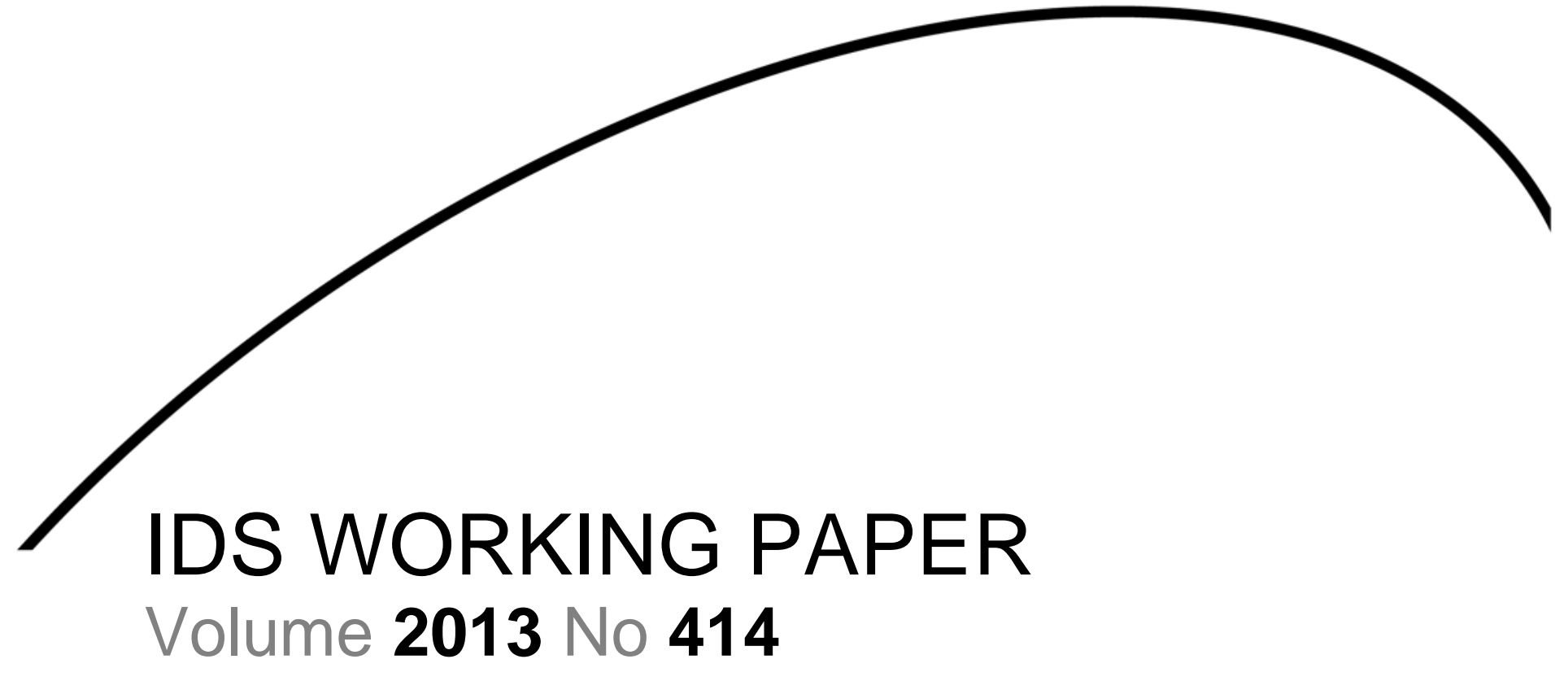

\title{
Does Better Provincial Governance Boost Private Investment in Vietnam?
}

Neil McCulloch, Edmund Malesky and Nhat Nguyen Duc January 2013

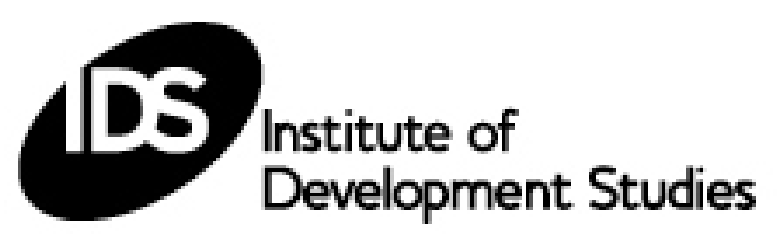


Does Better Provincial Governance Boost Private Investment in Vietnam? Neil McCulloch, Edmund Malesky and Nhat Nguyen Duc

IDS Working Paper 414

First published by the Institute of Development Studies in January 2013

(C) Institute of Development Studies 2013

ISSN: 2040-0209 ISBN: 978-1-78118-103-4

A catalogue record for this publication is available from the British Library.

All rights reserved. Reproduction, copy, transmission, or translation of any part of this publication may be made only under the following conditions:

- with the prior permission of the publisher; or

• with a licence from the Copyright Licensing Agency Ltd., 90 Tottenham Court Road, London, W1P 9HE, UK,

or from another national licensing agency; or

- under the terms set out below.

This publication is copyright, but may be reproduced by any method without fee for teaching or nonprofit purposes, but not for resale. Formal permission is required for all such uses, but normally will be granted immediately. For copying in any other circumstances, or for reuse in other publications, or for translation or adaptation, prior written permission must be obtained from the publisher and a fee may be payable.

\section{Available from:}

Central Communications, Institute of Development Studies, Brighton BN1 9RE, UK

Tel: +44 (0) 1273915637 Fax: +44 (0) 1273621202

E-mail: bookshop@ids.ac.uk

Web: www.ids.ac.uk/ids/bookshop

IDS is a charitable company limited by guarantee and registered in England (No. 877338) 


\title{
Does Better Provincial Governance Boost Private Investment in Vietnam?
}

\author{
Neil McCulloch, Edmund Malesky and Nhat Nguyen Duc
}

\section{Summary}

A large literature asserts a causal relationship between the quality of economic governance and economic performance. However, attempts to establish such a link at an aggregate level have met with considerable methodological criticism. This paper seeks to overcome this limitation. We match a panel of Vietnamese enterprises from 2006-2010 with a unique panel dataset measuring sub-national economic governance, and then exploit rules on the terms of local leaders and the mandatory retirement age to try to estimate a causal link between local governance and domestic private investment. With one exception, we do not find a significant relationship between most aspects of local economic governance and private investment. The exception is transparency, which is strongly associated with higher investment, although the weakness of our instruments makes it difficult to determine the size of the effect. Our results have significant implications for policy, given the prevailing assumption that changes in the quality of local economic governance will spur improved economic performance.

Keywords: investment climate, economic governance, Vietnam, sub-national, investment, economic reform

Neil McCulloch is Lead Economist of the Australian Aid Programme in Indonesia. He was formerly a Fellow of IDS and Leader of its Globalisation Team.

Edmund Malesky is Associate Professor of Political Science at Duke University and the developer behind Vietnam's Provincial Competitiveness Index.

Nhat Nguyen Duc is Lead Researcher of Vietsurvey with a long track record of research and advisory work on governance, trade and investment. 


\section{Contents}

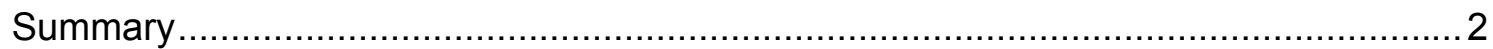

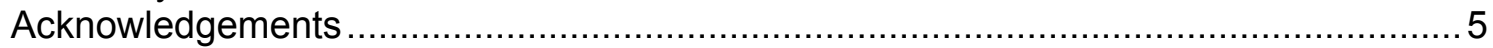

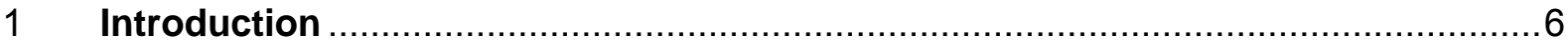

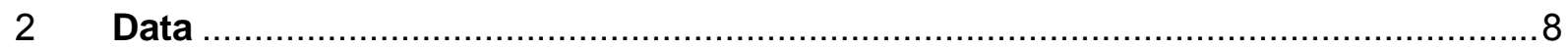

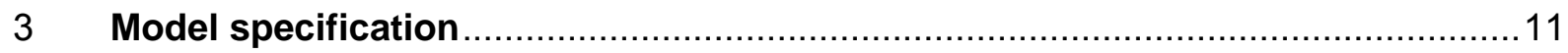

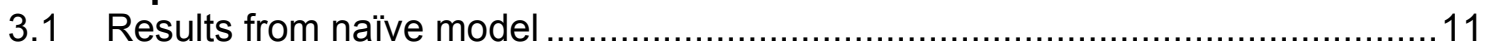

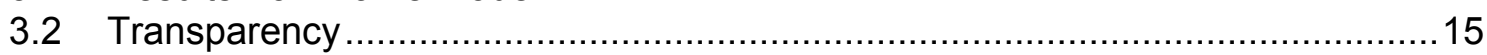

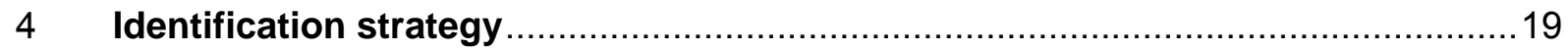

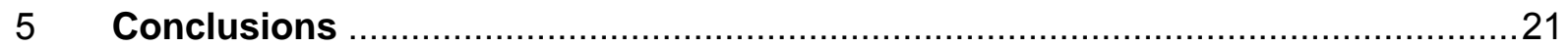

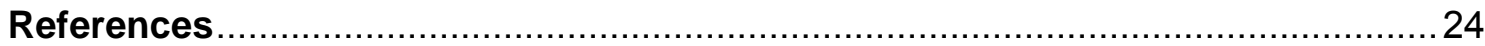

\section{Tables}

Table 2.1

Table 3.1

Table 3.2

Table 3.3

Table 4.1

Table 4.2

Characteristics of firms in the Enterprise Census................................... 10

Correlates of firm level investment ................................................... 13

Indicators for provincial transparency scores ...................................... 16

Transparency and firm level investment growth ..................................... 18

First stage determinants of governance ..............................................20

Determinants of investment growth (IV-2SLS) ................................... 21 


\section{Acknowledgements}

First and foremost, we would like to thank Professor Hubert Schmitz for his leadership of the ESRC-DFID Research Programme on 'Challenging the Investment Climate Paradigm:

Governance, Investment and Poverty Reduction in Vietnam' and his constant support and encouragement throughout the project. We gratefully acknowledge comments, ideas and support from the Vietnam Chamber of Commerce and Industry and, in particular, Pham Thi Thu Hang, Dau Anh Tuan and their friendly and helpful teams; Dirk Willenbockel also provided a helpful set of comments. The Government Statistical Office of Vietnam kindly provided access to the Enterprise Survey and other data. We gratefully acknowledge funding from the Economic and Social Research Council of the UK and DFID. Naturally all errors are our own. 


\section{Introduction}

The last two decades have witnessed a rapid expansion of the literature on the relationship between institutions, governance and economic performance. Starting with the seminal work of North $(1981,1989,1990)$ there has been an appreciation of the importance of institutions particularly those associated with the enforcement of contracts and the protection of property rights - in creating the incentives that give rise to economic growth (see Helpman (2008) for several recent studies).

A fundamental dilemma facing all of these studies is the difficulty of showing a causal relationship between institutions and economic performance. After all, it is perfectly possible that economic growth provides the resources for and generates popular demand for better quality institutions. Considerable ingenuity has been expended to attempt to show a causal link running from institutions to economic performance. Most famously, Acemoglu et al. (2001) use settler mortality as an instrument for colonial institutions in an attempt to establish this causal link. They argue that whether settlers in early colonies set up high quality institutions or not was influenced by the prevailing disease environment. In places with high mortality, settlers did not, or could not, install good institutions, whereas in places where the environment was more benign, they did. Acemoglu et al. argue that, since early settler mortality is not plausibly related to long-run economic performance except through the influence that it had on institutional development, it can provide a mechanism of identifying the causal relationship between institutions and economic performance.

However, the view of a strong causal link between institutions and economic performance is not universally accepted. For example, Glaeser et al. (2004) argue that some measures of institutions currently in use reflect outcomes (such as respect for property rights) rather than structural institutional determinants. They find little relationship between measures of these deeper structural determinants and economic performance, but a potentially strong role for initial human capital. They argue that the available evidence supports the idea that good policies give rise to growth which then results in institutional improvements. ${ }^{1}$

Work by Kaufmann and Kraay (2002) reinforces the idea that the relationship between governance and growth may be bi-directional. They find a strong positive causal relationship running from better governance to higher per capita incomes, but also a weak and sometimes negative relationship running from per capita income to governance. They argue that this suggests the absence of 'virtuous circles' in which higher income leads to further improvements in governance.

One of the weaknesses of most studies in this area is that they have focused on crosscountry data. Whilst this provides a large sample of countries and a relatively long time span, such studies are open to the criticism that there are important unobserved factors (e.g. culture) which may have an important influence upon economic performance and which are also correlated with governance, creating the possibility of biased estimates of the relationship between governance and growth.

To combat these issues of causality, a more recent group of scholars have begun to look at variation in governance across sub-national units within countries, and have exploited natural experiments in the creation of institutions or policy to better identify the causal path between

Moreover, there is dispute over which factors are most important in shaping institutions. Sokoloff and Engerman (2000) suggest that it is initial endowments, rather than the effect of disease patterns on colonial settlement, that determined the nature of the institutions constructed in different countries. They show how extractive institutions controlled by elites could perpetuate inequality which in turn slows economic performance and reinforces the institutional status quo (a theme expounded in detail by Acemoglu and Robinson (2012)). 
governance and economic performance. Because their data are higher quality and their measurement more exacting, these scholars have been better able to test the micro-logics that inform the theories linking governance and growth. For example, advances have been made in testing the relationship between property rights and entrepreneurial activity (Galiani and Scargrodsky 2006, Di Tella et al. 2007, Field 2007, Banerjee and lyer 2005, Malesky and Taussig 2009).

Sub-national studies have the strong advantage that the overarching political and legal framework and, to some extent, aspects of culture and language are more similar within the boundaries of a single country than they are across all countries in the world (although some countries have enormous diversities of ethnicity, culture and language within their borders). Sub-national analysis of this kind is becoming increasingly relevant for policy as many countries move towards greater political, fiscal and administrative decentralisation. Indeed, central governments and donor agencies often have an explicit objective of improving governance at the sub-national level on the grounds that this will improve local economic growth. Again, this assumes that the causal relationship runs from governance to growth; if the relationship ran in the other direction, then efforts to improve local institutions might have little impact on economic performance.

One of the difficulties in resolving the causal impact of governance on local economic performance is that the measurement of performance in some studies is still at a rather aggregate level e.g. sub-national GDP growth. To address this, several researchers have narrowed the focus to the impact of governance on Foreign Direct Investment (FDI). There is a very large literature on the determinants of FDI which typically points to traditional location advantages, including factor endowments, market attraction, labour costs and physical infrastructure as key to attracting FDI. ${ }^{2}$

In our country of focus - Vietnam - Le (2007) provides a comprehensive analysis of the subnational determinants of FDI and finds that agglomeration economies play a key role in attracting investors. Similarly, Pham Huong Mai (2002), Nguyen Phuong Hoa (2002), Meyer and Nguyen (2005), Mirza (2003, 2004), Nguyen Phi Lan (2006), and Nguyen Ngoc Anh and Nguyen Thang (2007), point to conventional determinants of FDI including economic growth, market size, human capital, labour costs and the quality of infrastructure.

Interestingly, this literature does not unequivocally point to the quality of local economic governance as a determinant of FDI. Although Malesky (2007) shows that there is a positive correlation between local economic governance and FDI, and Huynh (2010) argues that the quality of local post-registration services played a key role in attracting FDI, Vo Hung Dung (2011) points out that productivity, income and investment did not increase in line with improvements in the business environment in the Mekong delta, and Ngyuen and Nguyen (2007) find no relationship between the quality of local economic governance and FDI.

There is also a growing literature suggesting that causality runs in the opposite direction i.e. that FDI influences local economic governance. Hewko $(2002,2003)$ and Lewis (2005) have provided a range of examples of how investors affect the policy environment in Eastern Europe and the Former Soviet Union. Malesky (2009) confirms this empirically, exploiting exogenous variation in countries' exchange rate movements to estimate the impact of FDI on reform progress in 27 Eastern European transition states. In Vietnam, Malesky (2004) describes the channels of FDI influence on governance in 10 provinces and Malesky (2008) shows empirically how FDI has empowered sub-national leaders to push forward reform. As Hall and Soskice (2001) argue, although institutions may be exogenous to individual firms, an area's population of firms creates pressures to establish institutions that best meet their

See Coughlin et al. (1991); Head et al. (1995) for evidence on the US and Cheng and Kwan (2000); Head and Ries (1996); and Wei et al. (1999) on China. Kinda (2010) provides an assessment of the determinants of FDI across 77 developing countries. 
needs. Thus, they argue, political and social institutions determine the nature of firms, while firms collectively support the institutions that they come to rely on.

Given the evidence for the bidirectional causality between sub-national governance and FDI, it is not surprising that the literature has struggled to find clear identification of the influence of local economic governance on FDI or other measures of economic performance. To achieve such identification requires three things. First, a narrow measure of economic performance at the firm level, rather than aggregate performance at the sub-national level; second, a time series for both economic performance and a credible measure of local economic governance; and, finally, a plausible source of exogenous variation in governance which does not influence firm-level economic performance other than through its effect on governance. This paper aims to provide all three of these. We exploit the Vietnam Enterprise Census from 2000-2010 which provides a rich set of firm-level data including information about (domestic) investment over the period. This is combined with data from the Vietnam Provincial Competitiveness Index (PCl) which measures several dimensions of provincial governance from 2005-2010. We exploit exogenous rules on term limits for provincial leaders and compulsory retirement age rules to try and identify a causal impact of governance on firm investment.

Our paper proceeds as follows. The next section describes our data and how we constructed our dataset. The following section elaborates our basic model and provides initial results. Section 4 then describes our identification strategy and presents the results from applying that strategy. The final section concludes.

\section{Data}

Our source of firm data is the Vietnam Enterprise Census. This is an annual census of all firms with more than 10 employees with an additional random sample of smaller firms. The data includes a wide range of information on firm characteristics including: sector, employees, assets, legal type, performance, source of capital, and investment. We have data from 2000 to 2010 . The number of enterprises increased rapidly over this period from 42,123 in 2000 , to over 250,000 in the later years, reflecting the strong growth in private sector activity over the decade. Unfortunately, matching firms across years for the early years is extremely difficult. However, from 2006, a standardised firm identifier was used allowing us to construct an (unbalanced) panel of firms from 2006-2010. ${ }^{3}$

Our final panel dataset contains 391,631 firms. Fifteen per cent of the firms are measured for all five years, but others are measured less frequently either because of firm entry and exit during the time period under investigation, or because they fell below the Government Statistical Office of Vietnam (GSO) threshold of ten employees for inclusion in the census in a particular year and therefore were only subject to random selection, leading to gaps in the data.

Table 2.1 shows the characteristics of the firms in the Enterprise Census broken down by year and firm size. As in many developing countries, the distribution of firms in Vietnam is strongly biased towards the bottom end, with a very large number of firms with a handful of employees and low revenues, assets, profits and levels of investment; conversely, there are a relatively small number of firms with substantial assets and investments.

\footnotetext{
In a few cases, we discovered duplicate (or triplicate or more) observations with the same firm id. In these cases we had no way of determining which of the firms was the true match across years, so we deleted all firms with duplicate identifiers from the dataset. The characteristics of the firms deleted were statistically indistinguishable from those that were retained, so there does not appear to have been any systematic reason for the duplications that occurred.
} 
Two interesting features arise from Table 2.1. First, we can see the rapid growth in the number of firms since 2005, with a 170 per cent increase over five years and particularly rapid growth of small firms. This likely reflects the official sanctioning of private sector activity through the Enterprise Law (2000) and the Unified Investment Law (2006). Secondly, Table 2.1 shows the impact of the 2008 macroeconomic crisis in Vietnam and the global financial crisis at the end of that year; median revenues, profits and investments fell markedly for small and medium sized firms between 2008 and 2009. Interestingly, the same is not true for large firms, suggesting they were in a better position to adjust to the shocks. The considerable heterogeneity amongst firms, as well as the existence of time-varying, covariate shocks has important implications for our identification strategy later.

To measure the quality of local economic governance we draw on the Provincial Competitiveness Index $(\mathrm{PCl})$. The $\mathrm{PCl}$ is a composite index of provincial economic governance which has been calculated each year since 2006 by the Vietnam Chamber of Commerce and Industry ( $\mathrm{VCCl}) .{ }^{4}$ It is based upon a mail-out survey to a random sample of firms in each province. ${ }^{5}$ The survey asks a range of questions about firms' perceptions of local economic governance, as well as concrete measures of their experience of local governance. A particular strength of the $\mathrm{PCl}$ is that it focuses on aspects of local governance which are under the control of the provincial administration. It therefore excludes factors such as the quality or availability of national roads, airports and ports which would bias the index in favour of larger cities or provinces. Firm responses to the questions are combined into a set of nine sub-indices ${ }^{6}$ reflecting provincial performance on:

- Entry costs

- Land access and tenure security

- Transparency

- Time costs of regulatory compliance

- Informal charges

- Proactivity of the provincial government

- Business support services

- Labour training

- Legal institutions.

Provincial scores on each sub-index represent the province's performance on that topic relative to the performance of other provinces in Vietnam. The overall $\mathrm{PCl}$ index is a combination of the sub-indices, yielding an overall score for the quality of economic governance in each province. ${ }^{7}$ The published PCI scores use a weighted sum of the subindices, with weights determined by the influence of each sub-index in predicting different aspects of firm performance. We use this published $\mathrm{PCl}$, since it is observable to decision makers in firms and in government.

One limitation of the annually announced $\mathrm{PCl}$ is that each year, minor changes are made in the methodology in order to keep up with current policy debates and accommodate the needs of stakeholders. Individual survey questions have been dropped, new questions added, and indicators re-coded over time. All of these re-calibrations have introduced additional error into the measurement of governance and limit the ability to compare scores

A pilot $\mathrm{PCl}$ was conducted in 2005 but this did not cover all provinces in the country.

$5 \quad$ The sampling frame for the survey is the list of firms provided by the provincial tax authority. For example, in $2007,6,700$ firms were chosen randomly from the list of 177,815 firms provided by the tax office. To ensure representativeness, the sample is stratified by legal type of enterprises, sector of business and age of firm.

6 From 2006 to 2008 an index measuring the extent of bias of the local economy towards State-Owned Enterprises was included in the PCl. However, widespread 'equitisation' of these SOEs made this less relevant and so this sub-index was removed from 2009 onwards.

7 For full details of the construction of the PCl, see VCCI (2008). 
in the survey over time. To address this problem, we created a mini-PCl, which re-constructs the entire index using only a consistent set of indicators and equal weights across time.

In addition to the Enterprise Census and $\mathrm{PCl}$ data, we also draw on a range of provincial statistics from the GSO Statistical Yearbook.

Table 2.1 Characteristics of firms in the Enterprise Census

\begin{tabular}{|c|c|c|c|c|c|c|}
\hline Year & 2005 & 2006 & 2007 & 2008 & 2009 & 2010 \\
\hline \multicolumn{7}{|c|}{$\begin{array}{l}\text { Small firms } \\
\text { (<10 employees) }\end{array}$} \\
\hline No. of firms & 57,496 & 72,558 & 86,340 & 114,279 & 147,555 & 174,142 \\
\hline Employees & 4 & 5 & 5 & 5 & 5 & 5 \\
\hline Revenues & 660 & 1,699 & 1,507 & 2,086 & 584 & 552 \\
\hline Profits & 1 & 7 & 10 & 14 & 2 & 2 \\
\hline Assets & 450 & 1,014 & 986 & 1,310 & 1,709 & 2,178 \\
\hline Investment & 312 & 500 & 609 & 876 & 318 & 1,126 \\
\hline \multicolumn{7}{|c|}{$\begin{array}{l}\text { Medium firms } \\
\text { (10-99 employees) }\end{array}$} \\
\hline No. of firms & 38,834 & 43,946 & 52,006 & 74,115 & 80,968 & 95,465 \\
\hline Employees & 20 & 19 & 19 & 18 & 18 & 18 \\
\hline Revenues & 2,720 & 2,760 & 3,535 & 4,281 & 3,370 & 3,475 \\
\hline Profits & 24 & 26 & 35 & 32 & 28 & 24 \\
\hline Assets & 2,100 & 2,500 & 2,760 & 3,541 & 4,746 & 6,614 \\
\hline Investment & 361 & 411 & 507 & 918 & 599 & 1,126 \\
\hline \multicolumn{7}{|c|}{$\begin{array}{l}\text { Large firms } \\
\text { (100+ employees) }\end{array}$} \\
\hline No. of firms & 8,633 & 8,893 & 9,986 & 11,084 & 11,794 & 13,334 \\
\hline Employees & 222 & 220 & 216 & 208 & 203 & 200 \\
\hline Revenues & 28,784 & 32,763 & 39,828 & 44,234 & 48,360 & 54,600 \\
\hline Profits & 256 & 349 & 521 & 382 & 676 & 671 \\
\hline Assets & 28,037 & 31,732 & 34,552 & 38,703 & 45,038 & 53,432 \\
\hline Investment & 2,100 & 2,203 & 2,986 & 3,200 & 3,300 & 3,371 \\
\hline \multicolumn{7}{|l|}{ All firms } \\
\hline No. of firms & 104,963 & 125,397 & 148,332 & 199,478 & 240,317 & 282,941 \\
\hline Employees & 8 & 7 & 8 & 8 & 7 & 7 \\
\hline Revenues & 1,392 & 2,429 & 2,241 & 3,028 & 1,231 & 1,215 \\
\hline Profits & 8 & 14 & 17 & 20 & 6 & 6 \\
\hline Assets & 1,000 & 1,507 & 1,512 & 2,000 & 2,439 & 3,317 \\
\hline Investment & 500 & 512 & 635 & 927 & 713 & 1,200 \\
\hline
\end{tabular}

Note: Figures are medians unless stated otherwise. Monetary values are in VND million. 


\section{Model specification}

Our empirical specification, which is simple and intentionally conservative, is displayed in the equation below.

$Y_{i t}=\beta_{o}+\beta_{1} * P C I_{i t}+\beta_{2} * \operatorname{Tel}_{i t}+\beta_{3} * \operatorname{Pop}_{i t}+\beta_{4} * S O E_{i t}+\eta_{i}+\varphi_{t}+\varepsilon_{i t}$,

The dependent variable $(Y)$ is the natural log of investment in a given year, indexed by the firm id $(i)$ and year $(t)$. Firm $(\eta)$ fixed effects are employed, so that the analysis can isolate the empirical effect of annual changes in governance on individual firm's investment decisions. This modelling decision essentially ensures that we are only looking at the impact of governance within individual firms. Time $(\varphi)$ captures shocks in the data that occur in particular years of the survey (i.e. entry into the WTO in 2007 or the global financial crisis in 2008) which may lead to correlation in the errors of respondents in those years. Using time fixed effects is a highly conservative approach that is less prone to spurious correlation caused by non-stationarity or serial correlation.

The key causal variable is $\mathrm{PCl}$, the $\mathrm{PCl}$ score for the province-year in which the firm was situated. Our core specification uses the unweighted $\mathrm{PCl}$ score that was reported in the annual reports for the $\mathrm{PCl}$ project (Malesky, multiple years). Subsequent specifications replace the unweighted $\mathrm{PCl}$ with the individual sub-indices in order to isolate which governance factor might actually be driving investment decisions. To ensure that the results were not influenced by the particular choice of variables or weights, we also re-ran all our analysis with the mini- $\mathrm{PCl}$ described earlier.

Firm fixed effects address time invariant confounders to the analysis; however, they do not entirely remove the potential for omitted variable bias. Time variant factors at the provincial level could lead to bias if they are correlated with both governance and investment decisions. At the firm-level, the key threat is privatisation (equitisation) of some large state owned enterprises (SOEs) over the course of the sample. To address the fact that firms' views of governance and investment calculus may change after privatisation, we add a dummy variable to capture the years that a firm was an SOE. At the province level, the quality of infrastructure and size of the provincial market both change over time in ways that could be correlated with both governance and investment. To address this possibility, we include them as control variables. We proxy infrastructure by the number of land lines per capita (Tel) and market size by population (Pop) within the province. Unfortunately, market size and telecommunications are highly correlated leading to multi-collinearity in some specifications. In the reported specifications, we usually report only the coefficients on telephones, although the effects of governance are robust to using population or both variables simultaneously.

All models utilise ordinary least squares (OLS) with robust standard errors clustered at the province level. Clustering is necessary because firms are nested within provinces, the level at which the $\mathrm{PCl}$ score is reported, and therefore there is a strong possibility that errors may be correlated among firms within the same province, leading to under-estimation of the true standard error.

\subsection{Results from naïve model}

Table 3.1 reports the results from the application of the above model. Panel 1 shows the results for the unweighted index and all nine sub-indices using the reported index (Actual $\mathrm{PCl})$. Panel 2 replicates all analyses with the Mini-PCl scores. 
The first thing to notice is that overall economic governance, whether measured by the actual unweighted $\mathrm{PCl}$ (Model 1) or mini-PCl (Model 11), is not significantly correlated with firm decisions to expand their investment. However, overall governance conflates a great deal of institutional mechanisms and policy processes. It is entirely possible that certain locations may excel at one aspect of governance while performing poorly on others. This would limit variation and make it difficult to detect an association with investment. Moreover, if a specific policy process is actually responsible for investment, including it in an additive index may simply create noise that obscures the identification of a relationship. To guard against this possibility, we replicated the original specification, but this time regressed investment on each individual sub-index of the PCI in Table 3.1 (Models 2-10 and Models 11-20).

Once again, the results are striking in the rejection of a robust relationship between governance and investment decisions. Only one aspect of governance is positively correlated with decisions to expand investment - transparency. ${ }^{8}$ This confirms the results of previous $\mathrm{PCl}$ reports, which have consistently found transparency to be the most influential sub-index in regression analyses.

Not only is the transparency score statistically significant, but the effect is quite large. A oneunit change (about one standard deviation) in the ten-point index is associated with a 6.5 per cent increase in firm investment. When we employ the more consistent Mini- $\mathrm{PCl}$, the effect is an even more pronounced 9 per cent increase. A one-unit change is well within the reach of a province's leadership. Over the timeframe covered by the $\mathrm{PCl}$, the average province improved its transparency (2006 to 2010 ) score by 0.8 points with a standard deviation of three points, implying that some provinces drastically improved their score over time. Ceteris paribus, a one standard deviation improvement in PCl scores between 2006 and 2010 would have been associated with between an 18 per cent and 27 per cent increase in total private sector investment in the province. In short, transparency appears to pay large dividends. 
Table 3.1 Correlates of firm level investment - Panel 1: Actual PCI scores

\begin{tabular}{|c|c|c|c|c|c|c|c|c|c|c|}
\hline $\begin{array}{l}\text { Dependent Variable = } \\
\text { Annual Investment } \\
\text { Growth }\end{array}$ & (1) & $(2)$ & (3) & $(4)$ & (5) & (6) & (7) & (8) & (9) & $(10)$ \\
\hline Unweighted PCI (lag) & & $\begin{array}{c}0.013 \\
(0.011)\end{array}$ & & & & & & & & \\
\hline Entry costs (lag) & & & $\begin{array}{c}0.001 \\
(0.073)\end{array}$ & & & & & & & \\
\hline Land (lag) & & & & $\begin{array}{c}0.013 \\
(0.050)\end{array}$ & & & & & & \\
\hline Transparency (lag) & & & & & $\begin{array}{l}0.065^{\star} \\
(0.036)\end{array}$ & & & & & \\
\hline Time costs (lag) & & & & & & $\begin{array}{l}-0.005 \\
(0.035)\end{array}$ & & & & \\
\hline Informal charges (lag) & & & & & & & $\begin{array}{l}-0.014 \\
(0.053)\end{array}$ & & & \\
\hline Proactivity (lag) & & & & & & & & $\begin{array}{l}-0.007 \\
(0.046)\end{array}$ & & \\
\hline Priv. dev't. (lag) & & & & & & & & & $\begin{array}{c}0.047 \\
(0.029)\end{array}$ & \\
\hline Labour policy (lag) & & & & & & & & & & $\begin{array}{c}0.017 \\
(0.035)\end{array}$ \\
\hline Legal policy (lag) & & & & & & & & & & \\
\hline $\begin{array}{l}\text { Telephones per capita } \\
\text { (In, lag) }\end{array}$ & $\begin{array}{c}0.983 \\
(0.711)\end{array}$ & $\begin{array}{c}1.013 \\
(1.115)\end{array}$ & $\begin{array}{c}1.281 \\
(1.171)\end{array}$ & $\begin{array}{c}1.205 \\
(1.240)\end{array}$ & $\begin{array}{c}0.833 \\
(1.150)\end{array}$ & $\begin{array}{c}1.257 \\
(1.153)\end{array}$ & $\begin{array}{c}1.293 \\
(1.211)\end{array}$ & $\begin{array}{c}1.324 \\
(1.338)\end{array}$ & $\begin{array}{c}0.852 \\
(1.017)\end{array}$ & $\begin{array}{c}1.257 \\
(1.155)\end{array}$ \\
\hline State owned enterprise & $\begin{array}{c}0.139 \\
(0.261) \\
\end{array}$ & $\begin{array}{c}0.056 \\
(0.432) \\
\end{array}$ & $\begin{array}{c}0.219 \\
(0.473) \\
\end{array}$ & $\begin{array}{c}0.179 \\
(0.460) \\
\end{array}$ & $\begin{array}{c}0.065 \\
(0.411) \\
\end{array}$ & $\begin{array}{c}0.209 \\
(0.419) \\
\end{array}$ & $\begin{array}{c}0.234 \\
(0.458) \\
\end{array}$ & $\begin{array}{c}0.228 \\
(0.466) \\
\end{array}$ & $\begin{array}{c}0.023 \\
(0.366) \\
\end{array}$ & $\begin{array}{c}0.202 \\
(0.415) \\
\end{array}$ \\
\hline $\begin{array}{l}\text { Year FE } \\
\text { Firm FE }\end{array}$ & $\begin{array}{l}\text { YES } \\
\text { YES }\end{array}$ & $\begin{array}{l}\text { YES } \\
\text { YES }\end{array}$ & $\begin{array}{l}\text { YES } \\
\text { YES }\end{array}$ & $\begin{array}{l}\text { YES } \\
\text { YES }\end{array}$ & $\begin{array}{l}\text { YES } \\
\text { YES }\end{array}$ & $\begin{array}{l}\text { YES } \\
\text { YES }\end{array}$ & $\begin{array}{l}\text { YES } \\
\text { YES }\end{array}$ & $\begin{array}{l}\text { YES } \\
\text { YES }\end{array}$ & $\begin{array}{l}\text { YES } \\
\text { YES }\end{array}$ & $\begin{array}{l}\text { YES } \\
\text { YES }\end{array}$ \\
\hline Constant & $\begin{array}{l}4.649^{* *} \\
(2.190)\end{array}$ & $\begin{array}{c}5.371 \\
(3.555) \\
\end{array}$ & $\begin{array}{c}4.127 \\
(3.795) \\
\end{array}$ & $\begin{array}{c}4.400 \\
(3.857) \\
\end{array}$ & $\begin{array}{c}5.065 \\
(3.447) \\
\end{array}$ & $\begin{array}{c}4.798 \\
(3.660) \\
\end{array}$ & $\begin{array}{c}4.098 \\
(3.802) \\
\end{array}$ & $\begin{array}{c}4.627 \\
(4.013) \\
\end{array}$ & $\begin{array}{l}5.751^{*} \\
(3.218)\end{array}$ & $\begin{array}{c}4.171 \\
(3.639) \\
\end{array}$ \\
\hline Observations & 438,578 & 376,091 & 376,091 & 376,091 & 376,091 & 376,091 & 376,091 & 376,091 & 376,091 & 376,091 \\
\hline Clusters & 64 & 64 & 64 & 64 & 64 & 64 & 64 & 64 & 64 & 64 \\
\hline R-squared & 0.728 & 0.754 & 0.754 & 0.754 & 0.754 & 0.754 & 0.754 & 0.754 & 0.754 & 0.754 \\
\hline RMSE & 1.344 & 1.364 & 1.364 & 1.364 & 1.364 & 1.364 & 1.364 & 1.364 & 1.364 & 1.364 \\
\hline
\end{tabular}

OLS regression with robust standard errors, clustered at province level, in parentheses $\left({ }^{* * *} p<0.01,{ }^{* *} p<0.05,{ }^{*} p<0.1\right)$ 
Table 3.1 Correlates of firm level investment - Panel 2: Mini PCI scores

\begin{tabular}{|c|c|c|c|c|c|c|c|c|c|c|}
\hline $\begin{array}{l}\text { Dependent Variable = Annual } \\
\text { Investment Growth }\end{array}$ & (11) & $(12)$ & (13) & $(14)$ & (15) & $(16)$ & $(17)$ & $(18)$ & (19) & (20) \\
\hline Unweighted PCI (lag) & $\begin{array}{c}0.007 \\
(0.013)\end{array}$ & & & & & & & & & \\
\hline Entry costs (lag) & & $\begin{array}{l}-0.009 \\
(0.093)\end{array}$ & & & & & & & & \\
\hline Land (lag) & & & $\begin{array}{c}0.060 \\
(0.045)\end{array}$ & & & & & & & \\
\hline Transparency (lag) & & & & $\begin{array}{l}0.091^{* *} \\
(0.036)\end{array}$ & & & & & & \\
\hline Time costs (lag) & & & & & $\begin{array}{l}-0.033 \\
(0.039)\end{array}$ & & & & & \\
\hline Informal charges (lag) & & & & & & $\begin{array}{c}-0.012 \\
(0.064)\end{array}$ & & & & \\
\hline Proactivity (lag) & & & & & & & $\begin{array}{l}-0.021 \\
(0.076)\end{array}$ & & & \\
\hline Priv. dev't. (lag) & & & & & & & & $\begin{array}{l}0.072^{* *} \\
(0.032)\end{array}$ & & \\
\hline Labour policy (lag) & & & & & & & & & $\begin{array}{c}0.023 \\
(0.040)\end{array}$ & \\
\hline Legal policy (lag) & & & & & & & & & & $\begin{array}{l}-0.014 \\
(0.046)\end{array}$ \\
\hline $\begin{array}{l}\text { Telephones per capita (In, } \\
\text { lag) }\end{array}$ & $\begin{array}{c}1.267 \\
(1.168)\end{array}$ & $\begin{array}{c}1.276 \\
(1.208)\end{array}$ & $\begin{array}{c}0.666 \\
(1.371)\end{array}$ & $\begin{array}{c}0.884 \\
(1.076)\end{array}$ & $\begin{array}{c}1.152 \\
(1.156)\end{array}$ & $\begin{array}{c}1.262 \\
(1.225)\end{array}$ & $\begin{array}{c}1.193 \\
(1.293)\end{array}$ & $\begin{array}{c}1.360 \\
(1.148)\end{array}$ & $\begin{array}{c}1.371 \\
(1.254)\end{array}$ & $\begin{array}{c}1.284 \\
(1.187)\end{array}$ \\
\hline State owned enterprise & $\begin{array}{c}0.213 \\
(0.428) \\
\end{array}$ & $\begin{array}{c}0.233 \\
(0.494) \\
\end{array}$ & $\begin{array}{c}-0.012 \\
(0.498) \\
\end{array}$ & $\begin{array}{c}0.090 \\
(0.385) \\
\end{array}$ & $\begin{array}{c}0.116 \\
(0.446) \\
\end{array}$ & $\begin{array}{c}0.235 \\
(0.426) \\
\end{array}$ & $\begin{array}{c}0.204 \\
(0.456) \\
\end{array}$ & $\begin{array}{c}0.205 \\
(0.433) \\
\end{array}$ & $\begin{array}{c}0.236 \\
(0.452) \\
\end{array}$ & $\begin{array}{c}0.224 \\
(0.435) \\
\end{array}$ \\
\hline Year FE & YES & YES & YES & YES & YES & YES & YES & YES & YES & YES \\
\hline Firm FE & YES & YES & YES & YES & YES & YES & YES & YES & YES & YES \\
\hline Constant & $\begin{array}{c}4.077 \\
(3.694)\end{array}$ & $\begin{array}{c}4.645 \\
(3.966)\end{array}$ & $\begin{array}{c}5.784 \\
(4.109)\end{array}$ & $\begin{array}{c}4.751 \\
(3.274)\end{array}$ & $\begin{array}{c}5.242 \\
(3.902)\end{array}$ & $\begin{array}{c}4.078 \\
(3.700)\end{array}$ & $\begin{array}{c}4.370 \\
(4.064)\end{array}$ & $\begin{array}{c}4.443 \\
(3.823)\end{array}$ & $\begin{array}{c}3.823 \\
(4.007)\end{array}$ & $\begin{array}{c}4.464 \\
(3.809)\end{array}$ \\
\hline Observations & 376,091 & 376,091 & 376,091 & 376,091 & 376,091 & 376,091 & 376,091 & 376,091 & 376,091 & 376,091 \\
\hline Clusters & 64 & 64 & 64 & 64 & 64 & 64 & 64 & 64 & 64 & 64 \\
\hline R-squared & 0.754 & 0.754 & 0.754 & 0.754 & 0.754 & 0.754 & 0.754 & 0.754 & 0.754 & 0.754 \\
\hline RMSE & 1.364 & 1.364 & 1.364 & 1.363 & 1.364 & 1.364 & 1.364 & 1.363 & 1.364 & 1.364 \\
\hline
\end{tabular}




\subsection{Transparency}

Given the standout performance of transparency, it is worth exploring this particular subindex in more detail. As noted above, $\mathrm{PCl}$ reports have often detailed the importance of transparency for firm decision-making. Remarking on the importance of transparency in Vietnam, the Vietnam Chamber of Commerce and Industry wrote:

In such an opaque business regulatory environment, it is difficult for entrepreneurs to make strategic decisions on investment as they lack the ability to accurately assess the associated costs and risks. Better and easier access for firms to legal and regulatory information, along with transparent administrative procedures should greatly diminish the current need for personal relationships in dealing with provincial authorities. When implemented properly, these measures should go a long way towards eliminating the practice of informal charges.

(VCCI 2008)

The transparency sub-index is a composite index created from eight indicators measured over time. It measures whether firms have access to the proper planning and legal documents necessary to run their business, whether those documents are equitably available, whether new policies and laws are communicated to firms and predictably implemented, and the business utility of the provincial web page. Indicators are divided into four baskets:

(1) Access to important legal and planning documents that may affect firms' strategic planning and risk calculations. ${ }^{9}$

(2) The equity and consistency of access to documentation - are relationships or negotiations required to obtain the needed information?

(3) Participation in the drafting of local regulations and providing input on implementation.

(4) Openness of the provincial web-page - a simple count of 15 documents and whether they can be obtained on the province's banner website with five points allotted for web traffic.

Table 3.2 provides the specific indicators used to create the overall sub-index. All measures are re-scaled to a 1 to 10 point index and averaged to create a province's final score within the year.

Since 2006, access to legislation has been better than access to planning documents, due to Vietnam's commitments under WTO accession, which required the publication of local gazettes. After peaking in 2008 , however, access to legal documentation in the median province has declined marginally while the gap between the most and least transparent provinces doubled. Similarly, access to planning documents, which is not required by WTO commitments, declined over the period, although an incremental improvement between 2010 and 2011 brought the median province back to its 2006 level. Access to planning documents is important for levelling the playing field between investors with connections to provincial governments and those without such links. Without transparency of land and infrastructure plans, investors may under-invest out of fear that changes in local plans will negatively affect them.

Each year, the $\mathrm{PCl}$ asks respondents to rank their access to government documentation necessary for operating a business on a five-point scale, ranging from 1) Impossible to 5) Very Easy. These documents divide neatly into two categories: 1) Legal Normative Documents (e.g. Central Laws, Provincial Implementing Documents, and the Provincial Budget) and 2) Planning Documents (e.g. State Investment Plans, Infrastructure Roll-Out Plans, Land-Use Maps). 
Table 3.2 Indicators for provincial transparency scores

\begin{tabular}{|c|c|c|c|c|c|c|c|c|}
\hline \multicolumn{9}{|l|}{ 1. Access to documentation } \\
\hline Indicator & Measure & 2005 & 2006 & 2007 & 2008 & 2009 & 2010 & 2011 \\
\hline \multirow{4}{*}{ Transparency of planning documents $^{\dagger}$} & Min & 1.90 & 2.25 & 2.20 & 2.25 & 2.13 & 2.00 & 2.29 \\
\hline & Median & 2.36 & 2.63 & 2.51 & 2.55 & 2.44 & 2.31 & 2.50 \\
\hline & Max & 3.80 & 3.17 & 2.96 & 2.79 & 3.08 & 2.62 & 3.04 \\
\hline & Correlation w/Previous Year & NA & $0.39^{*}$ & $0.64^{*}$ & $0.61^{*}$ & $0.49^{*}$ & $0.48^{*}$ & \\
\hline \multirow{4}{*}{$\begin{array}{l}\text { Transparency of legal decisions and } \\
\text { decrees }^{\dagger}\end{array}$} & Min & 2.05 & 2.86 & 2.63 & 2.80 & 2.68 & 2.79 & 2.58 \\
\hline & Median & 2.81 & 3.15 & 3.05 & 3.11 & 3.11 & 3.05 & 3.04 \\
\hline & Max & 3.71 & 3.53 & 3.38 & 3.36 & 3.61 & 3.44 & 3.83 \\
\hline & Correlation w/Previous Year & NA & $0.31^{*}$ & $0.61^{*}$ & $0.59^{*}$ & $0.38^{*}$ & $0.56^{*}$ & \\
\hline \multicolumn{9}{|l|}{ 2. Equity and consistency of access } \\
\hline Indicator & Measure & 2005 & 2006 & 2007 & 2008 & 2009 & 2010 & 2011 \\
\hline \multirow{4}{*}{$\begin{array}{l}\text { Relationship important or very important to } \\
\text { get access to provincial documents (\% } \\
\text { Important or Very Important) }\end{array}$} & Min & 50 & 31.48 & 38.4 & 33.57 & 45.57 & 37.28 & 41.52 \\
\hline & Median & 72.11 & 62.5 & 56.6 & 49.82 & 61.26 & 78.64 & 75.00 \\
\hline & Max & 100 & 77.14 & 73.4 & 67.9 & 78.26 & 95.71 & 93.33 \\
\hline & Correlation w/Previous Year & NA & 0.27 & $0.38^{*}$ & $0.55^{*}$ & $0.37^{*}$ & $0.30^{*}$ & \\
\hline \multirow{4}{*}{$\begin{array}{l}\text { Negotiations with tax authority are an } \\
\text { essential part of doing business (\% Agree or } \\
\text { Strongly Agree) }\end{array}$} & Min & 52.17 & 47.17 & 24.1 & 17.39 & 29.69 & 23.75 & 7.58 \\
\hline & Median & 75.22 & 61.05 & 44.7 & 36.71 & 41.32 & 40.78 & 40.51 \\
\hline & Max & 96.15 & 86.96 & 73.2 & 54,25 & 62.4 & 67.04 & 63.16 \\
\hline & Correlation w/Previous Year & NA & -0.16 & $0.52^{*}$ & $0.73^{*}$ & $0.36^{*}$ & $0.27^{*}$ & \\
\hline \multirow{4}{*}{$\begin{array}{l}\text { Predictability of implementation of central } \\
\text { laws at the provincial level (\% Usually or } \\
\text { Always) }\end{array}$} & Min & 4.35 & 2.76 & 1.89 & 1.03 & 3.57 & 2.38 & 0.00 \\
\hline & Median & 14.91 & 9.49 & 7.96 & 6.94 & 8.4 & 8.97 & 8.57 \\
\hline & Max & 60.38 & 37.88 & 18.3 & 15.69 & 22.22 & 20.24 & 29.49 \\
\hline & Correlation w/Previous Year & NA & $0.38^{*}$ & $0.46^{*}$ & $0.3^{*}$ & $0.50^{*}$ & 0.10 & \\
\hline \multirow{4}{*}{$\begin{array}{l}\text { Friends important for negotiating with } \\
\text { government (\% Important or Very Important) }\end{array}$} & Min & 34.35 & 37.74 & 38.7 & 40 & & & \\
\hline & Median & 56.07 & 57.21 & 54.7 & 53.04 & DROPPED & DROPPED & DROPPED \\
\hline & Max & 80 & 82.35 & 65.1 & 67.47 & & & \\
\hline & Correlation w/Previous Year & NA & 0.22 & $0.45^{*}$ & $0.55^{*}$ & & & \\
\hline
\end{tabular}




\begin{tabular}{|c|c|c|c|c|c|c|c|c|}
\hline \multicolumn{9}{|l|}{ 3. Participation in local decision making } \\
\hline Indicator & Measure & 2005 & 2006 & 2007 & 2008 & 2009 & 2010 & 2011 \\
\hline $\begin{array}{l}\text { Do business associations play an important } \\
\text { role in advising and countering provincial } \\
\text { polices (\% Important or Very Important) } \\
\text { NEW INDICATOR }\end{array}$ & $\begin{array}{l}\text { Min } \\
\text { Median } \\
\text { Max } \\
\text { Correlation w/Previous Year }\end{array}$ & & & & & $\begin{array}{c}18.64 \\
35.71 \\
57.32 \\
\text { NA } \\
\end{array}$ & $\begin{array}{l}15.15 \\
37.04 \\
55.56 \\
0.32^{*}\end{array}$ & $\begin{array}{l}13.64 \\
31.37 \\
60.61\end{array}$ \\
\hline $\begin{array}{l}\text { Firm gives comments on government } \\
\text { regulation }(\%)^{*} \text { NEW INDICATOR }\end{array}$ & $\begin{array}{l}\text { Min } \\
\text { Median } \\
\text { Max } \\
\text { Correlation w/Previous Year }\end{array}$ & & & & & $\begin{array}{c}15.04 \\
25.21 \\
43.9 \\
\text { NA }\end{array}$ & $\begin{array}{l}11.36 \\
22.37 \\
38.35 \\
0.55^{\star}\end{array}$ & $\begin{array}{c}4.9 \\
15.8 \\
35.4\end{array}$ \\
\hline $\begin{array}{l}\text { Province discussed changes in laws with you } \\
\text { (\% Usually or Always) }\end{array}$ & $\begin{array}{l}\text { Min } \\
\text { Median } \\
\text { Max } \\
\text { Correlation w/Previous Year }\end{array}$ & $\begin{array}{c}0 \\
12.16 \\
61.54 \\
\text { NA } \\
\end{array}$ & $\begin{array}{c}0 \\
8.84 \\
20.9 \\
-0.29 \\
\end{array}$ & $\begin{array}{c}0.9 \\
7.57 \\
21.62 \\
0.45^{*} \\
\end{array}$ & $\begin{array}{l}1.21 \\
8.57 \\
18.6 \\
0.52^{\star}\end{array}$ & DROPPED & DROPPED & DROPPED \\
\hline $\begin{array}{l}\text { Services provided by provincial agencies: } \\
\text { consulting on national and provincial } \\
\text { regulations ( } \% \text { Very Good or Good). }\end{array}$ & $\begin{array}{l}\text { Min } \\
\text { Median } \\
\text { Max } \\
\text { Correlation w/Previous Year }\end{array}$ & & $\begin{array}{c}24.49 \\
48.05 \\
60.94 \\
\text { NA }\end{array}$ & $\begin{array}{c}30.3 \\
48.28 \\
72.84 \\
0.63^{*}\end{array}$ & $\begin{array}{c}6.67 \\
20.08 \\
33.77 \\
0.53^{*}\end{array}$ & DROPPED & DROPPED & DROPPED \\
\hline \multicolumn{9}{|l|}{ 4. Openness of provincial web page } \\
\hline Indicator & Measure & 2005 & 2006 & 2007 & 2008 & 2009 & 2010 & 2011 \\
\hline Openness of provincial web page score ${ }^{\psi}$ & $\begin{array}{l}\text { Min } \\
\text { Median } \\
\text { Max } \\
\text { Correlation w/Previous Year }\end{array}$ & $\begin{array}{c}0 \\
10 \\
\\
\\
\end{array}$ & $\begin{array}{c}0 \\
9 \\
18 \\
0.36^{*}\end{array}$ & $\begin{array}{c}0 \\
13.75 \\
20 \\
0.51^{*}\end{array}$ & $\begin{array}{c}0 \\
14.25 \\
20 \\
0.70^{*}\end{array}$ & $\begin{array}{c}0 \\
15 \\
20 \\
0.74^{*}\end{array}$ & $\begin{array}{c}0.00 \\
15.00 \\
19.00 \\
0.79^{*}\end{array}$ & $\begin{array}{c}9.00 \\
15.00 \\
20.00\end{array}$ \\
\hline
\end{tabular}

* Significant at $5 \%$ level; NA = not applicable.

All values are at the provincial level.

2005 data only include 42 provinces.

${ }^{\dagger}$ Indicators result from factor analysis of 13 documents. In 2009, the scale was simplified to reflect the average access on a 5 pt. scale

(1 very difficult to 5 very easy).

In 2007 and 2008, 0.5 values were allowed to denote provinces that provided the relevant information, but not in a sufficient manner to

be useful.

** Only business association members respond. 
Table 3.3 Transparency and firm level investment growth

\begin{tabular}{|c|c|c|c|c|c|c|c|c|}
\hline \multirow[b]{2}{*}{$\begin{array}{l}\text { Dependent Variable = } \\
\text { Annual Investment Growth }\end{array}$} & \multicolumn{4}{|c|}{ Using actual PCI scores } & \multicolumn{4}{|c|}{ Using mini-PCl scores } \\
\hline & $\begin{array}{c}\text { Trans } \\
(1)\end{array}$ & $\begin{array}{c}\text { Infra } \\
(2)\end{array}$ & $\begin{array}{l}\text { Pop } \\
(3)\end{array}$ & $\begin{array}{l}\text { SOE } \\
(4)\end{array}$ & $\begin{array}{c}\text { Trans } \\
(5)\end{array}$ & $\begin{array}{c}\text { Infra } \\
(6)\end{array}$ & $\begin{array}{l}\text { Pop } \\
(7)\end{array}$ & $\begin{array}{l}\text { SOE } \\
(8)\end{array}$ \\
\hline \multicolumn{9}{|l|}{ Unweighted PCI (lag) } \\
\hline Transparency (lag) & $\begin{array}{l}0.073^{* *} \\
(0.034)\end{array}$ & $\begin{array}{l}0.067^{*} \\
(0.034)\end{array}$ & $\begin{array}{l}0.065^{*} \\
(0.036)\end{array}$ & $\begin{array}{l}0.065^{\star} \\
(0.036)\end{array}$ & $\begin{array}{l}0.099^{* * *} \\
(0.037)\end{array}$ & $\begin{array}{l}0.093^{* *} \\
(0.036)\end{array}$ & $\begin{array}{l}0.091^{* *} \\
(0.036)\end{array}$ & $\begin{array}{l}0.091^{* *} \\
(0.036)\end{array}$ \\
\hline $\begin{array}{l}\text { Telephones per capita (In, } \\
\text { lag) }\end{array}$ & & $\begin{array}{l}0.673^{* * *} \\
(0.228)\end{array}$ & $\begin{array}{c}0.833 \\
(1.150)\end{array}$ & $\begin{array}{c}0.835 \\
(1.151)\end{array}$ & & $\begin{array}{l}0.660^{* * *} \\
(0.226)\end{array}$ & $\begin{array}{c}0.884 \\
(1.076)\end{array}$ & $\begin{array}{c}0.886 \\
(1.076)\end{array}$ \\
\hline Population (In, lag) & & & $\begin{array}{c}0.065 \\
(0.411)\end{array}$ & $\begin{array}{c}0.066 \\
(0.411)\end{array}$ & & & $\begin{array}{c}0.090 \\
(0.385)\end{array}$ & $\begin{array}{c}0.091 \\
(0.385)\end{array}$ \\
\hline State owned enterprise & & & & $\begin{array}{c}0.220 \\
(0.178)\end{array}$ & & & & $\begin{array}{c}0.219 \\
(0.178)\end{array}$ \\
\hline Year FE & YES & YES & YES & YES & YES & YES & YES & YES \\
\hline Firm FE & YES & YES & YES & YES & YES & YES & YES & YES \\
\hline Constant & $\begin{array}{c}5.738^{\star * *} \\
(0.198) \\
\end{array}$ & $\begin{array}{l}5.604^{* * *} \\
(0.220)\end{array}$ & $\begin{array}{l}5.065 \\
(3.447) \\
\end{array}$ & $\begin{array}{c}5.054 \\
(3.448) \\
\end{array}$ & $\begin{array}{l}5.639^{* * *} \\
(0.203)\end{array}$ & $\begin{array}{l}5.509^{* * *} \\
(0.208)\end{array}$ & $\begin{array}{c}4.751 \\
(3.274)\end{array}$ & $\begin{array}{c}4.740 \\
(3.275) \\
\end{array}$ \\
\hline Observations & 377,072 & 376,091 & 376,091 & 376,091 & 377,072 & 376,091 & 376,091 & 376,091 \\
\hline Clusters & 64 & 64 & 64 & 64 & 64 & 64 & 64 & 64 \\
\hline R-squared & 0.754 & 0.754 & 0.754 & 0.754 & 0.754 & 0.754 & 0.754 & 0.754 \\
\hline RMSE & 1.364 & 1.364 & 1.364 & 1.364 & 1.364 & 1.363 & 1.363 & 1.363 \\
\hline
\end{tabular}

OLS regression with robust standard errors, clustered at province level, in parentheses $\left({ }^{* * *} p<0.01,{ }^{* *} p<0.05,{ }^{*} p<0.1\right)$ 
One of the reasons why some provinces score poorly on transparency is that personal relationships can be of critical importance for accessing business documentation. Three quarters of investors in the median province believe that having friends or family in government is important for accessing planning and legal documents (up from 52 per cent in 2007). It is unclear why personal connections have grown in importance over time, but their salience likely affects the efficiency of businesses in two ways. First, by favouring those with connections instead of those with the best ideas and talent, local governments negatively influence the quality of businesses in their province. Second, all investors must invest time and resources into developing connections that might be better spent on their operations.

Table 3.3 subjects the transparency finding to multiple robustness tests to see whether the coefficient remains stable with different combinations of firm and province-level control variables. With both actual and Mini- $\mathrm{PCl}$ data, the relationship remains strongly robust.

\section{Identification strategy}

The regressions above suggest that transparency is causally related to increases in investment. However, the simple model above does not prove that this is the case, because there are a number of other ways in which the observed results might be coming about. This section considers possible criticisms of our attempt to identify a causal effect and applies an instrumental variable approach to addressing the most serious potential critique.

While simultaneity bias is an unlikely concern, as it is difficult to imagine how individual firm investment decisions could influence provincial transparency, unobserved heterogeneity remains a serious threat to causal identification. One form of this is the notion of halo effects - that firms' satisfaction with their own business success colours their views of the quality of local governance (Kurtz and Schrank 2007). One would imagine, however, that halo effects would affect every sub-index and not just transparency, especially because the presence of the web page results makes it less reliant on solely perceptions based measures. Another form of unobserved heterogeneity is that a third, unobserved, feature of the province (i.e. culture or entrepreneurial history) is driving both annual changes in investment and improvements in governance. In Vietnam, this argument has been made about the South, which only spent 11 years under strict central planning and has long been thought to have more dynamic business managers and leaders than the rest of the country (Nguyen et al. 2004).

To address this problem, we rely on a quasi-experiment provided by exogenous leadership changes over the course of the sample. People's Committee chairmen are allowed by law to only serve two terms, before seeking higher office in Hanoi or as party secretary of the province. Because of the prospects for promotion, People's Committee Chairmen have a strong incentive to generate stellar economic performance in their latter term. If they are especially strategic, they may even seek to dampen performance in the first term to highlight the growth in the second period (See Whiting 2000, Landry 2008, Gang 2009, and Xu 2011 for evidence of such behaviour in China). Thus, we expect a second-year chairman to have greater performance on economic governance than newly appointed leaders. There is, however, an exception to this hypothesis, which is second-term leaders who are approaching the mandatory retirement age of 65 may not be as willing to pursue dramatic governance reforms in the twilight of their careers. Without the prospect of promotion before them, other motivations may prevail, such as the willingness to not rock the boat for future leaders or, in cases of especially problematic governance, retiring leaders may use the second term to protect rents acquired over the course of their tenure. We use these insights as the basis for an instrumental variables strategy. We regress transparency on two instruments: 1) a 
dichotomous variable if the People's Committee chairman is in his/her second term; 2) a dichotomous variable if the chairman will turn 65 during the second term.

These results are displayed in Table 4.1 below. The results confirm our hypotheses. Chairmen in their second terms are more likely to pursue transparency reforms. Having a second-term chairman is associated with a 0.1 movement in the ten-point transparency score. This does not seem like much until we consider that the average annual change in provincial scores was -0.06 . On the other hand, retiring officials were not reform oriented as we predicted. Having a retiring chairman was associated with 0.22 smaller changes in transparency.

Table 4.1 First stage determinants of governance

\begin{tabular}{lcc}
\hline Dependent Variable=Transparency & $\begin{array}{c}\text { Actual } \\
(1)\end{array}$ & $\begin{array}{c}\text { Mini } \\
(2)\end{array}$ \\
\hline Chairman reached retirement age & $-0.220^{* *}$ & $-0.141^{* *}$ \\
& $(0.095)$ & $(0.066)$ \\
Chairman is in second term & $0.099^{*}$ & 0.063 \\
& $(0.051)$ & $(0.047)$ \\
State owned enterprise & $-0.051^{* *}$ & $-0.050^{* *}$ \\
& $(0.022)$ & $(0.020)$ \\
Telephone per capita (In, lag) & $0.819^{* * *}$ & $0.858^{* * *}$ \\
& $(0.271)$ & $(0.228)$ \\
Unweighted (lag) & & \\
& & \\
Transparency (lag) & $0.527^{* * *}$ & $0.549^{* * *}$ \\
& $(0.047)$ & $(0.046)$ \\
\hline Year FE & YES & YES \\
Firm FE & YES & YES \\
\hline Constant & $3.063^{* * *}$ & $3.244^{* * *}$ \\
& $(0.311)$ & $(0.282)$ \\
\hline Observations & 614,849 & 614,849 \\
Clusters & 63 & 63 \\
R-squared overall & 0.542 & 0.527 \\
RMSE & 0.480 & 0.457 \\
\hline
\end{tabular}

OLS regression with robust standard errors, clustered at province level, in parentheses $\left({ }^{* * *} p<0.01,{ }^{* *} p<0.05,{ }^{*} p<0.1\right)$

Unfortunately, standard metrics for measuring instrument strength, such as the Wald-F test and Sargan diagnostic indicate that although the correlation is significant, the relationship is weak. The instruments explain too little of the overall variation in reform effort. Weak instruments have been shown to be associated with bias in the second stage (Bound et al. 1995). This finding can be observed in Table 4.2, where we report the second stage results. The coefficients on the first lag of transparency, the variable predicted by the instrument are strongly significant, but are also heavily inflated. For instance, in the case of the actual PCI score, the coefficient is ten times the size of the naïve model. Consequently, while we feel comfortable that the direction of the causal effect of transparency is robust, we cannot provide precision on the size of that effect once endogeneity is taken into consideration.

Weak instrument strength is difficult to overcome in this case, as only 10 leaders (out of 357) reached their second term in our sample. Although these leaders presided over 32,000 firm 
years (about 10 per cent of our sample), there is simply too little power in the province-level of analysis to precisely estimate the effect of the term-limit.

Table 4.2 Determinants of investment growth (IV-2SLS)

\begin{tabular}{lcc}
\hline $\begin{array}{l}\text { Dependent Variable }=\text { Annual Investment } \\
\text { Growth }\end{array}$ & Actual & Mini \\
$(1)$ & $(2)$ \\
\hline Transparency (lag) & $0.598^{*}$ & 0.440 \\
& $(0.335)$ & $(0.286)$ \\
Transparency (lag 2) & $0.150^{* *}$ & $0.087^{* *}$ \\
& $(0.057)$ & $(0.040)$ \\
State owned enterprise & $0.289^{* *}$ & $0.257^{* *}$ \\
& $(0.126)$ & $(0.126)$ \\
Telephones per capita (In, lag) & -0.478 & -0.322 \\
& $(0.794)$ & $(0.703)$ \\
\hline Year FE & YES & YES \\
Firm FE & YES & YES \\
\hline Observations & 248,238 & 248,238 \\
Clusters & 64 & 64 \\
R-squared & 0.011 & 0.026 \\
\hline Sargan P & 0.386 & 0.498 \\
Sargan statistic & 1.906 & 1.393 \\
\hline
\end{tabular}

OLS regression with robust standard errors, clustered at province level, in parentheses $\left({ }^{* * *} p<0.01,{ }^{* *} p<0.05,{ }^{*} p<0.1\right)$

\section{Conclusions}

This paper set out to try and pin down the causal relationship between governance reform and private investment in Vietnam. As the literature shows, this is not an easy task, since the impact is potentially confounded by endogeneity, halo effects, unobserved heterogeneity and insufficiently precise measures of the relevant variables, particularly when they are measured at an aggregate level. We argued in the introduction that successful identification would require three things: a narrow measure of economic performance at the firm level and over time; a time series of credible measures of local economic governance; and a plausible source of exogenous variation in governance which does not influence firm-level economic performance other than through its effect on governance.

By focusing on firm-level investment data from the Vietnam Enterprise Census we have a precise measure of economic performance. Using the PCI panel, we have a rich and credible set of governance indicators at the local level. Together these allow us to effectively address both individual time-invariant heterogeneity and covariate time-varying shocks. Moreover, by exploiting exogenous characteristics associated with term limits and the provincial leader's age we have constructed a plausible identification strategy. Unfortunately, our instruments are too weak to have any reasonable degree of confidence in the size of the effect identified; the estimated coefficients for the impact of transparency on investment are clearly inflated as a result. However, we believe that we have identified a clear causal impact of transparency on private sector investment (and equally found that many other aspects of local governance have no discernible impact on investment).

We find the substance of our results striking. First, consider what we did not find. We find no evidence for a systematic causal relationship between most aspects of local economic 
governance and private investment. To recap, we discern no impact on investment from: lower entry costs, better access to land, smaller time costs, reduced informal charges, a more pro-active local government, better private sector development programmes, greater labour flexibility, and a better legal environment. This is quite remarkable since, as discussed earlier, there is a voluminous literature suggesting that each of these is important for boosting private investment and growth. Indeed many government and donor programmes focus on reducing entry costs (consider the huge policy emphasis in recent years on the time and cost to start an enterprise arising, in part, from the World Bank's Doing Business surveys). Similarly, there has been considerable policy effort on reducing corruption and informal charges, promoting flexible labour markets and improving legal certainty. The fact that these aspects of governance do not appear to have a reliable association with private investment is puzzling.

What are the possible reasons for not observing a robust association between these aspects of governance and private investment? One possibility is that an important effect exists, but that we still have not found it. There is a huge amount of noise in firm-level data, particularly in investment - it could be that this noise is swamping important effects. Whilst we cannot deny that this is possible, we are not convinced by this argument; we have an extremely large dataset and employ an extremely conservative strategy to account for heterogeneity. Indeed, it is hard to conceive of a better dataset for exploring this question (unless one had the power to impose random governance shocks on sub-national governments).

Another possibility is that the effects exist but are masked by negative reverse causality from economic performance to local economic governance (Kaufmann and Kraay 2002). In general, we find this idea attractive - it is entirely possible that, as countries or regions grow, the quality of their local economic governance deteriorates as actors attempt to capture rents. Moreover, Schmitz et al. (2012) find strong qualitative evidence of the role of the private sector in both driving and blocking economic reform in Vietnam's provinces. However, in our particular context, it seems implausible that individual firm investments (of the very small size that dominate our dataset) are going to have a material impact upon the province's economic governance.

Thus, a little like Sherlock Holmes, we conclude that 'When you have eliminated the impossible, whatever remains, however improbable, must be the truth.' That is, we suggest that the above aspects of local economic governance, in fact, have a minimal impact upon firm investment. That does not mean that they are not desirable. Indeed, many surveys suggest that these are the sorts of changes that investors want. However, it is possible that these changes are introduced over time as economies and institutions develop, but have no particularly strong causal impact upon performance. As an analogy, improving local economic governance may be a bit like improving the interior design of your house - having nicely painted walls, pleasant pictures and comfortable furniture may make you feel good but it has no discernible impact on the ability of the house to keep you warm and dry. Similarly, improving local economic governance may make investors' lives more comfortable, but they will invest when there are opportunities, and put up with (and lobby to reduce) the discomfort as they go along.

Our second major conclusion appears to contradict our first. We do find a (probably) strong causal connection between transparency and private investment. Why should we observe an association with transparency, but not with any of the other aspects of governance measured? One possibility is that transparency and access to information are more fundamental requirements than the other aspects measured. If entrepreneurs are not able to access information about opportunities, they are unlikely to invest. Similarly, if they cannot obtain basic legal and regulatory information they will not even consider investing. Thus transparency may have a critical role in reducing the risks associated with investments. Another possibility is that transparency - by reducing the need for personal connections - 
encourages more widespread investment. Without transparency, only those with personal connections can receive the assurances necessary to invest; with clear rules and processes, even those unconnected to the local elite can consider investment. Returning to our 'house' analogy - transparency would appear to be part of the House (along with public infrastructure, the existence of a key opportunity and proximity to markets) rather than part of the interior décor of policy. We are hopeful that future research will be able to pin down the precise pathways through which transparency affects private investment- and ascertain why so many other aspects of local economic governance appear to have so little effect. 


\section{References}

Acemoglu, Daron and Robinson, James A. (2012) Why Nations Fail: The Origins of Power, Prosperity and Poverty, New York: Crown Publishers

Acemoglu, Daron; Johnson, Simon and Robinson, James A. (2001) 'The Colonial Origins of Comparative Development: An Empirical Investigation', The American Economic Review 91.5: 1369-1401

Banerjee, Abhijit and lyer, Lakshmi (2005 'History, Institutions and Economic Performance: The Legacy of Colonial Land Tenure Systems in India', American Economic Review 95.4: $1190-1213$

Bound, John; Jaeger, David A. and Baker, Regina M. (1995) 'Problems with Instrumental Variables Estimation When the Correlation Between the Instruments and the Endogeneous Explanatory Variable is Weak', Journal of the American Statistical Association 90.430: 443-50

Cheng, Leonard K. and Kwan, Yum K. (2000) 'What are the Determinants of the Location of Foreign Direct Investment? The Chinese Experience', Journal of International Economics 51: 379-400

Coughlin, Cletus C.; Terza, Joseph V. and Arromdee, Vachira (1991) 'State Characteristics and the Location of Foreign Direct Investment within the United States', Review of Economics and Statistics 73.4: 675-83

Di Tella, Rafael; Galiani, Sebastian and Schargrodsky, Ernesto (2007) 'The Formation of Beliefs: Evidence from the Allocation of Land Titles to Squatters', The Quarterly Journal of Economics 122.1: 209-41

Field, Erica (2007) 'Entitled to Work: Urban Tenure Security and Labor Supply in Peru', The Quarterly Journal of Economics 122.4: 1561-1602

Galiani, Sebatian and Schargrodsky, Ernesto (2010) 'Property Rights for the Poor: Effects of Land Titling', Journal of Public Economics 94.9-10: 700-29

Gang Guo (2009) 'China's Local Political Budget Cycles', American Journal of Political Science 53.3: 621-32

Glaeser, Edward L.; La Porta, Rafael; Lopez-de-Silanes, Florencio and Shleifer, Andrei (2004) 'Do Institutions Cause Growth?', Journal of Economic Growth 9.3: 271-303

Hall, Peter A. and Soskice, David (eds) (2001) Varieties of Capitalism: The Institutional Foundations of Comparative Advantage, Oxford: Oxford University Press

Head, Keith and Ries, John (1996) 'Inter-city Competition for Foreign Investment: Static and Dynamic Effects of China's Incentive Areas', Journal of Urban Economics 40.1: 38-60 
Head, Keith: Ries, John and Swenson, Deborah L. (1995) 'Agglomeration Benefits and Location Choice: Evidence from Japanese Manufacturing Investments in the United States', Journal of International Economics 38.3-4: 223-47

Helpman, Elhanan (2008) Institutions and Economic Performance, Cambridge Mass.: Harvard University Press

Hewko, John (2003) 'Foreign Direct Investment in Transitional Economies: Does the Rule of Law Matter?', East European Constitutional Review (F2002/W2003): 71-79

Hewko, John (2002) 'Foreign Direct Investment in Transitional Economies: Does the Rule of Law Matter?', Carnegie Endowment Working Paper Series 26, April

Huynh Minh Chac (2010) 'Public Support for Investors', Journal of Foreign InvestmentVietnam Association of Foreign Invested Enterprises, Special edition in June 2010

Kaufmann, Daniel and Kraay, Aart (2002) 'Growth Without Governance', World Bank Policy Research Working Paper 2928, Washington D.C., November

Kinda, Tidiane (2010) 'Investment Climate and FDI in Developing Countries: Firm-Level Evidence', World Development 38.4: 498-513

Kurtz, Marcus J. and Schrank, Andrew (2007) 'Growth and Governance: Models, Measures, and Mechanisms', Journal of Politics 69.2: 538-54

Landry, Pierre F. (2008) Decentralized Authoritarianism in China: The Communist Party's Control of Local Elites in the Post-Mao Era, Cambridge and New York: Cambridge University Press

Le, Thuy Le (2007) 'Subnational Determinants of Foreign Direct Investment: The Case of Vietnam', PhD Dissertation, Faculty of the College of Arts and Sciences, UMI No. 3273597, American University, Washington D.C.

Lewis, Charles Paul (2005) How the East Was Won: The Impact of Multinational Companies on Eastern Europe and the Former Soviet Union. New York: Palgrave Macmillan

Malesky, Edmund J. (multiple years) 'The Vietnam Provincial Competitiveness Index: Measuring Economic Governance for Private Sector Development. 2008 Final Report', Vietnam Competitiveness Initiative Policy Paper \#13-18, Vietnam Chamber of Commerce and Industry (VCCI) and United States Agency for International Development's Vietnam Competitiveness Initiative (VNCl), Ha Noi, Vietnam

Malesky, Edmund J. (2009) 'Foreign Direct Investors as Agents of Economic Transition: An Instrumental Variables Analysis', Quarterly Journal of Political Science 4.1: 59-85

Malesky, Edmund J. (2008) 'Straight Ahead on Red: How Foreign Direct Investment Empowers Subnational Leaders', The Journal of Politics 70.1: 97-119 
Malesky, Edmund J. (2007) 'Provincial Governance and Foreign Direct Investment in Vietnam', Saigon Economic Times, submitted 2 December 2007, Knowledge Publishing House

Malesky, Edmund J. (2004) 'Push, Pull and Reinforcing: the Channels of FDI Influence on Provincial Governance in Vietnam', in Benedict J. Tria Kerkvliet and David G. Marr (eds), Beyond Hanoi, Local Government in Vietnam, ISEAS

Malesky, Edmund J. and Taussig, Markus (2009) 'Out of the Gray: The Impact of Provincial Institutions on Business Formalization in Vietnam', Journal of East Asian Studies 9.2: 249-90

Meyer, Klaus E. and Nguyen, Hung Vo (2005) 'Foreign Investment Strategies and Subnational Institutions in Emerging Markets: Evidence from Vietnam', Journal of Management Studies 42.1: 63-93

Mirza, Hafiz and Giroud, Axele (2004) 'Regional Integration and Benefits from Foreign Direct Investment in ASEAN Countries: The Case of Vietnam', Asian Development Economic Review 21.1: 66-98

Mirza, Hafiz and Giroud, Axele (2003) 'The Impact of Foreign Direct Investment on the Economic Development of ASEAN Economy - A Preliminary Analysis', paper presented at EAMSA 20th Annual Conference, Stockholm School of Business.'

Nguyen Dinh Cung, Pham Anh Tuan, Bui Van, and Dapice, David (2004) 'Why Don't Northern Provinces Grow Faster?', Hanoi: Central Institute for Economic Management and United Nations Development Program

Nguyen Ngoc Anh and Nguyen Thang (2007) 'Foreign Direct Investment in Vietnam: an Overview and Analysis of Key Determinants of Spatial Distribution across Vietnam', Munich Personal RePEc Archive

Nguyen Phi Lan (2006) 'Foreign Direct Investment in Vietnam: Impact on Economic Growth and Domestic Investment', mimeo, Centre for Regulation and Market Analysis, University of South Australia

Nguyen Thi Phuong Hoa (2002) 'Contribution of Foreign Direct Investment to Poverty Reduction: The Case of Vietnam', mimeo

North, Douglass C. (1990) Institutions, Institutional Change and Economic Performance, Cambridge: Cambridge University Press

North, Douglass C. (1989) 'Institutions and Economic Growth: An Historical Introduction', World Development 17.9: 1319-32

North, Douglass C. (1981) Structure and Change in Economic History, New York: W.W. Norton

Pham Hoang Mai (2002) 'Regional Economic Development and Foreign Direct Investment Flows in Vietnam, 1988-98', Journal of the Asia Pacific Economy 7.2: 182-202 
Schmitz, Hubert; Dau Anh Tuan; Pham Thi Thu Hang and McCulloch, Neil (2012) Who Drives Economic Reform in Vietnam's Provinces?, IDS Research Report 76, Brighton: IDS

Sokoloff, Kenneth L. and Engerman, Stanley L. (2000) 'History Lessons: Institutions, Factor Endowments and Paths of Development in the New World', Journal of Economic Perspectives 14.3: 217-32

VCCI (2008) 'Provincial Economic Governance and its Impact on Local Competitiveness', Vietnam Chamber of Commerce and Industry, Business Issues Bulletin (IFC-MPDF), No.23 (26) March: 1-4

Vo Hung Dung (2011) 'Mekong Delta 2001-2010 Economic Review and Ways Ahead', Journal of Economics and Development, Vietnam National Economics University

Wei, Yingqi; Liu, Xiaming; Parker, David and Vaidya, Kirit (1999) 'The Regional Distribution of Foreign Direct Investment in China', Regional Studies 33.9: 857-67

Whiting, Susan H. (2000) Power and Wealth in Rural China: The Political Economy of Institutional Change. Cambridge, New York and Melbourne: Cambridge University Press

Xu, Chengang (2011) 'The Fundamental Institutions of China's Reforms and Development', Journal of Economic Literature 49.4: 1076-1151 